\title{
Loyalty among online food delivery customers: Extended scale of e-service quality
}

\author{
Hendrick Hernando* \\ PT Dirgantara Indonesia (Persero) \\ Jl. Pajajaran 154, Bandung 40174, Indonesia \\ hendrick@indonesian-aerospace.com \\ Wely Hadi Gunawan \\ Department of Management, Universitas Kuningan \\ Jl. Cut Nyak Dhien 36A, Kuningan 45513, Indonesia \\ welyhadigunawan@uniku.ac.id
}

*Penulis Korespondensi

Submitted: Mar 11, 2021; Reviewed: Mar 24, 2021; Accepted: Apr 22, 2021

\begin{abstract}
Considering the contradictory finding regarding e-service quality influence toward customer loyalty in the context of online food delivery (OFD) service, we evaluate e-service quality measurement by adding an extended indicator. Our study aims to validate payment flexibility as an extended indicator and examine e-service quality influence on customer loyalty. Data were collected through an online questionnaire involving 100 OFD customers in West Java (Indonesia). The Partial Least Square (PLSSEM) technique was used to analyze data from that answered questionnaire. Interestingly, our findings showed that payment flexibility is valid and reliable as an e-service quality indicator. Moreover, the influence of e-service quality on OFD customer loyalty is found to be statistically significant. Finally, this study provides new insight into the existing knowledge of e-service quality and generates valuable implications. OFD service providers are suggested to ensure order suitability in retaining their customer loyalty.
\end{abstract}

Keywords: customer loyalty; e-service quality; online food delivery; payment flexibility

Abstrak: Memertimbangkan hasil kontradiktif mengenai pengaruh kualitas layanan elektronik terhadap loyalitas pelanggan pada konteks layanan pesan-antar makanan daring, kami mengevaluasi pengukuran kualitas layanan elektronik dengan melibatkan sebuah indikator tambahan. Studi ini bertujuan untuk memvalidasi fleksibilitas pembayaran sebagai indikator tambahan dan menguji pengaruh dari kualitas layanan elektronik terhadap loyalitas pelanggan. Data dikumpulkan melalui kuesioner daring dengan melibatkan 100 orang pelanggan di Jawa Barat (Indonesia). Teknik Partial Least Square (PLS-SEM) digunakan untuk menganalisis data hasil pengisian kuesioner. Hasil studi ini memerlihatkan fleksibilitas pembayaran valid dan reliabel sebagai indikator kualitas layanan elektronik. Selain itu, pengaruh dari kualitas layanan elektronik terhadap loyalitas pelanggan telah terbukti signifikan. Studi ini memberikan wawasan baru mengenai kualitas layanan elektronik dan menghasilkan implikasi yang bernilai. Para penyedia jasa disarankan untuk memastikan kesesuaian pesanan dalam menjaga loyalitas pelanggan.

Kata kunci: fleksibilitas pembayaran; kualitas layanan elektronik; loyalitas pelanggan; pesan-antar makanan daring 


\section{INTRODUCTION}

Social distancing during the COVID-19 pandemic has increased online food delivery (hereafter as OFD) transactions worldwide (Cai \& Leung, 2020; Chang \& Meyerhoefer, 2020; Dannenberg et al., 2020). According to Jakarta Post (2020), the OFD platform owned by Gojek (GoFood) achieved 10 percent monthly transaction growth in early May 2020. This phenomenon has occurred due to purchase behavior shifting during the pandemic outbreak, whereas the societies would feel more secure through the online transaction. Considering the current condition, GoFood has focused on service quality improvement by operational simplification and weekly culinary programs.

Electronic-based service quality (hereafter as e-service quality) plays a critical role in retaining customer loyalty, especially in the business ecosystem with high online interaction (Amin, 2016; Shankar \& Jebarajakirthy, 2019). Khan et al. (2019) have argued that current customers might easily switch due to widely accessible information, then the business practitioners must focus on their equality service improvement. Through online interaction conducted on the websites or smartphonebased systems, customers build their-own perception regarding the company's service quality (Raza et al., 2020). Moreover, some studies (Kaya et al., 2019; Khan et al., 2019) have empirically proved the significant influence of e-service quality on customer loyalty.

Although the critical role of e-service quality in enhancing customer loyalty has been empirically confirmed based on the proper conceptual foundation, a study by Suhartanto et al. (2018) found a contradictory result. Their study involved 405 OFD customers in Bandung (Indonesia) and adopted ES-QUAL measurement scale. This identified research gap drives us to evaluate e-service quality measurement in the context of OFD service by considering possibilities to recommend another indicator. We extend the ES-QUAL scale by involving payment flexibility as an indicator and also empirically examine the influence of e-service quality on customer loyalty.

As has been expected before, Indonesia becomes the fast-growing market for digital payment providers. Both local and foreign players, including (GoPay, LinkAja, OVO, and AliPay), would set up Indonesia as the next digital payment battleground, which started in early 2021 (Jakarta Post, 2020). Societies have more preferred cashless transactions due to the popularity of smartphones and third-party payment applications (Boden et al., 2020; Liu et al., 2020), no exception for the OFD service context. Considering those explained phenomena, we decide to recommend payment flexibility as an extended indicator in our study.

Hereafter, this study provides several contributions, including theoretical and managerial aspects. Since it was initially introduced by Parasuraman et al. (2005), to the best of our knowledge, there is a lack of study that involves payment flexibility within the ES-QUAL scale, particularly for OFD service topics. About that consideration, this study would contribute valuable insights for the development and application of the ES-QUAL scale during the cashless era. From the managerial perspective, this study can be a fundamental concern to establish suitable strategies in retaining customers, mainly for OFD service providers.

\section{1 lnvolving payment flexibility into ES-QUAL scale}

ES-QUAL scale, rooted in the expectancy disconfirmation theory, has attracted much attention from business researchers worldwide. Expectancy disconfirmation theory reveals that individual satisfaction is generated from two compared expectations, including expectations from the actual performance (of products or services) and personal predetermined standard (Filtenborg et al., 2017; Qazi et al., 2017). The ES-QUAL scale development consists of two main stages, exploratory study (focus-group research) and confirmatory factor analysis (Parasuraman et al., 2005; Zeithaml et al., 2000). That development process successfully identified the ES-QUAL scale within four dimensions (i.e., efficiency, fulfillment, system availability, and privacy).

Although the ES-QUAL scale has been widely used in many studies, controversies arise due to the measurement relevance, mainly when dealing with the specific service attributes (Blut, 2016; Ladhari, 2010). For instance, the fulfillment dimension becomes more suitable in web-based retailing (ecommerce), but it needs adjustment for other industries (e.g., banking, education, hospitality, etc.). It means that the selected dimensions depend on the involved industry and its service characteristic 
(Ladhari, 2010). Based on that consideration, we propose payment flexibility into the ES-QUAL scale and examine it within the OFD context.

More specifically, payment flexibility is selected due to the following reasons. Payment flexibility was proposed in an early stage of the ES-QUAL scale development, but it was eliminated in the second stage due to construct validity reasons (Parasuraman et al., 2005; Zeithaml et al., 2000). After a decade, it becomes more relevant with the emergence of several method alternatives such as virtual account, prepaid account (e-wallet), cash on delivery (COD) etc. (Putri et al., 2019). Moreover, digital payment utilization has significantly raised during the COVID-19 pandemic due to health protocol compliance (Aji et al., 2020; Dannenberg et al., 2020).

\subsection{Hypothesis development}

A high level of e-service quality is directly proportional to higher customer retention, especially for online businesses (Amin, 2016; Kaya et al., 2019). OFD service user, which is categorized as the internet-based customer, tend to show their switching behavior. That behavior appears due to ease of information access, particularly about price and service features comparison (Kaya et al., 2019). Customers would evaluate service quality based on experience of use (via website or application) and then decide to conduct repurchase action (Kedah et al., 2015; Khan et al., 2019; Suhartanto et al., 2018).

In the OFD service context, routine maintenance on the ordering application is critical to protect customer commitment (Alalwan, 2020). Continuous evaluation for the application is also needed to enhance the reliability and quality of OFD service. Specifically, the reliable and proper application would affect positively to customer experience. Therefore, maintenance should be more focused on the user features improvement. Based on the above elucidation, we propose the following hypothesis.

H1: E-service quality positively influences the loyalty of OFD service customers.

\section{METHOD}

\subsection{Data analysis}

This study aims to validate payment flexibility as an extended ES-QUAL indicator and also examine the proposed hypothesis. Partial least squares structural equation modeling (hereafter as PLS-SEM) was applied to accommodate those objectives. According to (Hair et al., 2019; Sarstedt et al., 2017), PLS-SEM as a multivariate technique is more suitable for exploratory or extension-based studies. Considering our concern to validate the possibilities of payment flexibility as an ES-QUAL indicator, PLS-SEM was chosen. We conducted the reflective model assessment at the first stage to verify our indicator. Moreover, the structural model assessment was employed at the second stage to examine our proposed hypothesis.

\subsection{Measurement scale}

Related to variable definition and indicator in this study, we adapted from the past studies with minor adjustment to represent OFD service context. We describe e-service quality as the extent to which the smartphone application accommodates OFD related activities effectively and efficiently (Suhartanto et al., 2018; Zeithaml et al., 2000). Meanwhile, customer loyalty is defined as the intention to repurchase food through the smartphone application along with positive behavior toward OFD service (Pee et al., 2019; Suhartanto et al., 2018). We employed five items to assess e-service quality, including four dimensions of the original ES-QUAL scale (Parasuraman et al., 2005) and payment flexibility as an extended indicator. Three indicator items (i.e., repurchase intention, positive word of mouth, and recommendation to others) were used to assess customer loyalty (Kaya et al., 2019; Suhartanto et al., 2018). We delivered all those measurement items based on a 10-point Likert scale (1 strongly disagree to 10 strongly agree). To ensure our questions are well understood, we pretested it toward $10 \mathrm{OFD}$ customers, containing undergraduate students and professional employees. From that pretested stage, our questionnaire received minor improvement related to the wording context. The detail of each measurement item is presented in Table 2. 


\subsection{Sample and data collection}

Considering the unknown population boundary, we applied purposive sampling (as a non-probability method) to collect data. According to Taherdoost (2016), the purposive sampling procedure is ideal for exploratory studies instead of generalization purposes. That sampling technique allows researchers to obtain essential information through a pre-determined particular setting. The sample necessity in this study refers to OFD customers who made transactions regularly. We used a minimum requirement of 1-3 monthly purchases for this context.

The required data were gathered through the online questionnaire, which is we utilized social media platform for its distribution process. Our questionnaire was distributed mainly for OFD customers in West Java Province around the end of December 2020, while respondents were given one month to answer it completely. After the mentioned answering period, a total of 100 respondents were obtained and involved in PLS-SEM analysis. We used the "ten times rule" to determine the minimum samplesized from the largest number of structural paths (Richter et al., 2016), which means that the minimum requirement was fulfilled.

\section{RESULT AND DISCUSSION}

\subsection{Respondents profile}

From those who answered the questionnaire, it can be found that the majority of respondents are under the age group of 21-30 years old. Most of the respondents are female and identified as undergraduate students. In terms of average purchase, almost half of the respondents conduct 3-5 transactions every month. These demographic profiles are similar to earlier OFD studies (Kedah et al., 2015; Suhartanto et al., 2018). The detail of respondents' profile is presented in Table 1.

Table 1. Demographic background of respondents

\begin{tabular}{llcc}
\hline Demographic variable & Description & Frequency & Precentage (\%) \\
\hline Gender & Male & 46 & 46,00 \\
& Female & 54 & 54,00 \\
Age & Less than 21 & 35 & 35,00 \\
& $21-30$ & 39 & 39,00 \\
& $31-40$ & 19 & 19,00 \\
Occupation & More than 40 & 7 & 7,00 \\
& Entrepreneur & 23 & 23,00 \\
\multirow{4}{*}{ Most used application } & Professional employee & 35 & 35,00 \\
& Undergraduate student & 42 & 42,00 \\
Monthly average purchase & GrabFood & 51 & 51,00 \\
& GoFood & 49 & 49,00 \\
& Less than 3 & 40 & 40,00 \\
& 3-5 & 44 & 44,00 \\
\hline
\end{tabular}

Source: Processed data (2021)

\subsection{Reflective model assessment}

As showed in Table 2, Cronbach's alpha (CA) and composite reliability (CR) for each latent construct fulfilled the cut-off value (should be higher than 0,70). Both CA and CR values represent sufficient proof for internal reliability (Hair et al., 2017). To measure convergent validity, we used the values of indicator loadings and average variance extracted (AVE). We found that all indicators loadings ranging from 0,67 to 0,84, which reached the cut-off value of 0,50 (Hair et al., 2009). AVE for each latent construct was higher than 0,50 , which means that convergent validity has been established (Hair et al., 2017). Meanwhile, the discriminant validity aspect was assessed using Heterotrait-Monotrait 
(HTMT) ratio. Our result of HTMT ratio between the latent constructs did not exceed 0,85 . It means that each latent construct is considered to be unique (Hair et al., 2017).

Table 2. Reflective model assessment results

\begin{tabular}{lcccc}
\hline Construct (Measurement item) & Loading & CA & CR & AVE \\
\hline E-Service quality & & 0,792 & 0,856 & 0,543 \\
- Easy to complete transaction via application & 0,793 & & & \\
- Application is always available and rarely crashes & 0,708 & & & \\
- The order arrived is represented correctly on the application & 0,799 & & & \\
- Application protects personal or confidential information & 0,674 & & & \\
- Application provides several alternatives of payment method & 0,703 & & & \\
Customer loyalty & & 0,737 & 0,845 & 0,645 \\
- Intention to repurchase through the preferred application & 0,842 & & & \\
- Say positive things about the preferred application & 0,723 & & & \\
- Recommend preferred application to other people & 0,840 & & & \\
\hline
\end{tabular}

Notes: CA (Cronbach Alpha); CR (Composite Reliability); AVE (Average Variance Extracted)

Source: Processed data (2021)

\subsection{Structural model assessment}

In the second stage, we applied bootstrapping procedure with 500 iterations to examine the proposed hypothesis. The bootstrapping process was conducted to obtain path coefficients in the structural model (see Fig. 1). Following Hair et al. (2017) recommendation, the significance of path coefficients was examined using resulted $t$-value. To represent explained variance on endogenous construct in our structural model, we used $R^{2}$ value. Meanwhile, the $Q^{2}$ value was used to evaluate the predictive relevance aspect. As presented in Table 3, e-service quality has a positive and significant influence on customer loyalty ( $t$-value $>2,57$ ). Afterward, e-service quality only able to explain $29,1 \%$ of customer loyalty based on $R^{2}$ value. It means that the other predictors have a portion of $70,9 \%$ to predict customer loyalty. Additionally, our model has predictive relevance since resulted $Q^{2}$ value is greater than zero.

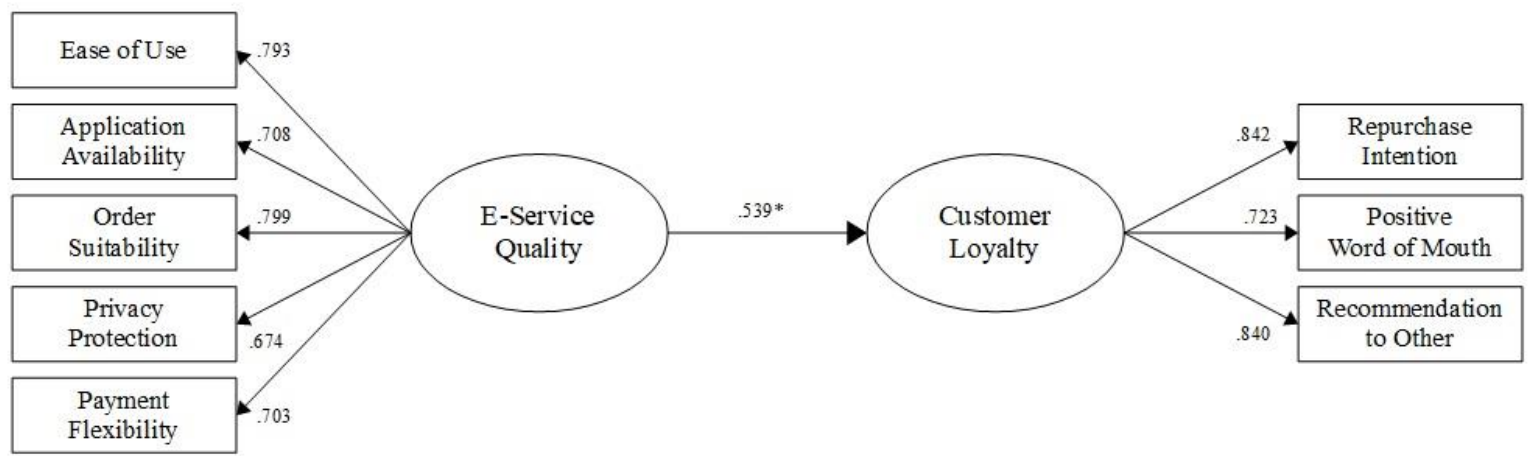

Fig. 1. Full PLS-SEM model

Source: Processed data (2021)

Table 3. Structural model assessment results

\begin{tabular}{lcccc}
\hline Hypothesis (Path) & $\beta$ & t-value & $\mathrm{R}^{2}$ & $\mathrm{Q}^{2}$ \\
\hline E-Service Quality $\rightarrow$ Customer Loyalty & 0,539 & $8,797^{*}$ & 0,291 & 0,167 \\
\hline
\end{tabular}

Notes: *significant at $p<0,01$

Source: Processed data (2021)

\subsection{Payment flexibility as an extended indicator}

The first stage analysis indicates that payment flexibility is valid and reliable as an e-service quality indicator. It stands out as the essential finding to meet our objectives pleasantly. Extend knowledge to 
the earlier OFD studies (Kedah et al., 2015; Suhartanto et al., 2018), our study demonstrates the beneficial role of payment flexibility, particularly in determining repurchase intention. As a possible justification for it, regarding health protocol compliance during the COVID-19 pandemic, customers tend to avoid conventional payment for their transactions (Aji et al., 2020; Dannenberg et al., 2020). Considering this finding, OFD service providers are suggested to increase collaboration with prepaid account providers. Through that collaboration, OFD service providers able to maintain flexibility and seek new potential customers.

\subsection{E-service quality influence on customer loyalty}

The present study aims to examine a contradictory result concerning the relationship between e-service quality and customer loyalty. Contrary to the previous finding from Suhartanto et al. (2018), this study found a significant influence of e-service quality on customer loyalty. Nevertheless, there is something that obtained consistently in terms of the highest contributor to reflect e-service quality. This study confirms the significant role of order suitability (as an e-service quality indicator) to enhance loyalty, mainly in the context of OFD service customers. Based on the expectancy disconfirmation perspective (Filtenborg et al., 2017; Qazi et al., 2017), we can understand that repurchase intention is generated from a suitability between food arrived and informed on the smartphone application. Regarding the inconsistent influence of e-service quality on customer loyalty, we suggest the chance of moderating variables in future studies.

\section{CONCLUSION AND RECOMMENDATION}

Our study has proved the essential role of payment flexibility as a valid indicator of e-service quality and found support for the hypothesized relationship. These findings provide evidence to increase our understanding, particularly about the ES-QUAL scale development in the OFD service context. In the cashless era caused by financial technology advancement and the COVID-19 pandemic outbreak, payment flexibility has been established as an appropriate indicator for e-service quality. Moreover, this study also suggests an important implication for OFD service providers. To retain the current customers, suitability between orders arrived to customers and displayed on the application must be maintained. OFD service providers are recommended to increase the control mechanism toward their merchant and driver-partners. That mentioned mechanism is useful to guarantee the quality of food ordered by the customers.

Although this study generates valuable understanding about the development and application of the ES-QUAL scale, it appears with certain limitations. First, according to the structural model assessment results, the $R^{2}$ value in this study is considered weak. In behavior-related studies, the $R^{2}$ value for endogenous construct is expected as 0,75 or higher (Hair et al., 2017). Based on that consideration, we recommend some determinant variables in future studies (e.g., customer satisfaction, food quality, etc.) Second, respondents may have various amounts regarding their monthly transactions, but it is not accommodated in the demographic profile. Information referring to customer purchasing power able to generate a better managerial implication, particularly for pricing strategy.

\section{REFERENCES}

Aji, H. M., Berakon, I., \& Husin, M. M. (2020). COVID-19 and e-wallet usage intention: A multigroup analysis between Indonesia and Malaysia. Cogent Business \& Management, 7(1), 1-16. https://doi.org/10.1080/23311975.2020.1804181

Alalwan, A. A. (2020). Mobile food ordering apps: An empirical study of the factors affecting customer e-satisfaction and continued intention to reuse. International Journal of Information Management, 50, 28-44. https://doi.org/10.1016/j.ijinfomgt.2019.04.008

Amin, M. (2016). Internet banking service quality and its implication on e-customer satisfaction and ecustomer loyalty. International Journal of Bank Marketing, 34(3), 280-306. https://doi.org/10.1108/IJBM-10-2014-0139

Blut, M. (2016). E-service quality: Development of a hierarchical model. Journal of Retailing, 92(4), 500-517. https://doi.org/10.1016/j.jretai.2016.09.002 
Boden, J., Maier, E., \& Wilken, R. (2020). The effect of credit card versus mobile payment on convenience and consumers' willingness to pay. Journal of Retailing and Consumer Services, 52, 1-10. https://doi.org/10.1016/j.jretconser.2019.101910

Cai, R., \& Leung, X. Y. (2020). Mindset matters in purchasing online food deliveries during the pandemic: The application of construal level and regulatory focus theories. International Journal of Hospitality Management, 91, 1-11. https://doi.org/10.1016/j.ijhm.2020.102677

Chang, H., \& Meyerhoefer, C. D. (2020). COVID-19 and the demand for online food shopping services: Empirical evidence from Taiwan. American Journal of Agricultural Economics, 103(2), 448-465. https://doi.org/10.1111/ajae.12170

Dannenberg, P., Fuchs, M., Riedler, T., \& Wiedemann, C. (2020). Digital transition by COVID-19 Pandemic? The German food online retail. Tijdschrift Voor Economische En Sociale Geografie, 111(3), 543-560. https://doi.org/10.1111/tesg.12453

Filtenborg, A. F., Gaardboe, F., \& Rasmussen, J. (2017). Experimental replication: An experimental test of the expectancy disconfirmation theory of citizen satisfaction. Public Management Review, 19(9), 1235-1250. https://doi.org/10.1080/14719037.2017.1295099

Hair, J. F., Black, W. C., Babin, B. J., \& Anderson, R. E. (2009). Multivariate data analysis (7th ed.). New Jersey, US: Prentice Hall

Hair, J. F., Hult, G. T. M., Ringle, C. M., \& Sarstedt, M. (2017). A primer on partial least squares structural equation modeling (2nd ed.). Thousand Oaks: Sage

Hair, J. F., Risher, J. J., Sarstedt, M., \& Ringle, C. M. (2019). When to use and how to report the results of PLS-SEM. European Business Review, 31(1), 2-24. https://doi.org/10.1108/EBR-112018-0203

Jakarta Post. (2020, May 14). GoFood sees double-digit increase in transactions during pandemic. https://www.thejakartapost.com

Jakarta Post. (2020, July 13). Why Indonesia is the world's next digital payments battleground. https://www.thejakartapost.com

Kaya, B., Behravesh, E., Abubakar, A. M., Kaya, O.S., \& Orús, C. (2019). The moderating role of website familiarity in the relationships between e-service quality, e-satisfaction, and e-loyalty. Journal of Internet Commerce, 18(4), 369-394. https://doi.org/10.1080/15332861.2019.1668658

Kedah, Z., Ismail, Y., Haque, A., \& Ahmed, S. (2015). Key success factors of online food ordering services: An empirical study. Malaysian Institute of Management, 50(2), 19-36. https://ur.aeu.edu.my/529

Khan, M. A., Zubair, S. S., \& Malik, M. (2019). An assessment of e-service quality, e-satisfaction and e-loyalty: Case of online shopping in Pakistan. South Asian Journal of Business Studies, 8(3), 283302. https://doi.org/10.1108/SAJBS-01-2019-0016

Ladhari, R. (2010). Developing e-service quality scales: A literature review. Journal of Retailing and Consumer Services, 17(6), 464-477. https://doi.org/10.1016/j.jretconser.2010.06.003

Liu, Y., Luo, J., \& Zhang, L. (2020). The effects of mobile payment on consumer behavior. Journal of Consumer Behaviour, 1-9. https://doi.org/10.1002/cb.1880

Parasuraman, A., Zeithaml, V. A., \& Malhotra, A. (2005). E-S-QUAL: A multiple-item scale for assessing electronic service quality. Journal of Service Research, 7(3), 213-233. https://doi.org/10.1177/1094670504271156

Pee, L., Jiang, J., \& Klein, G. (2019). E-store loyalty: Longitudinal comparison of website usefulness and satisfaction. International Journal of Market Research, 61(2), 178-194. https://doi.org/10.1177/1470785317752045

Putri, Y. E., Wiryono, S. K., Nainggolan, Y. A., \& Cahyono, T. D. (2019). Method of payment adoption in Indonesia e-commerce. The Asian Journal of Technology Management, 12(2), 94-102. https://doi.org/10.12695/ajtm.2019.12.2.2

Qazi, A., Tamjidyamcholo, A., Raj, R. G., Hardaker, G., \& Standing, C. (2017). Assessing consumers' satisfaction and expectations through online opinions: Expectation and disconfirmation approach. Computers in Human Behavior, 75, 450-460. https://doi.org/10.1016/j.chb.2017.05.025

Raza, S. A., Umer, A., Qureshi, M. A., \& Dahri, A. S. (2020). Internet banking service quality, ecustomer satisfaction and loyalty: The modified e-SERVQUAL model. The TQM Journal, 32(6), 1443-1466. https://doi.org/10.1108/TQM-02-2020-0019

Richter, N. F., Sinkovics, R. R., Ringle, C. M., \& Schlägel, C. (2016). A critical look at the use of SEM in international business research. International Marketing Review, 33(3), 376-404. https://doi.org/10.1108/IMR-04-2014-0148

Sarstedt, M., Ringle, C. M., \& Hair, J. F. (2017). Partial least squares structural equation modeling. In C. Homburg, M. Klarmann, \& A. Vomberg (Eds.), Handbook of Market Research (pp. 1-40). Springer International Publishing

Shankar, A., \& Jebarajakirthy, C. (2019). The influence of e-banking service quality on customer loyalty: A moderated mediation approach. International Journal of Bank Marketing, 37(5), 11191142. https://doi.org/10.1108/IJBM-03-2018-0063 
Jurnal Manajemen Maranatha ø Vol. 20 Nomor 2, Mei (2021)

Suhartanto, D., Ali, M. H., Tan, K. H., Sjahroeddin, F., \& Kusdibyo, L. (2018). Loyalty toward online food delivery service: The role of e-service quality and food quality. Journal of Foodservice Business Research, 22(1), 81-97. https://doi.org/10.1080/15378020.2018.1546076

Taherdoost, H. (2016). Sampling methods in research methodology: How to choose a sampling technique for research. International Journal of Academic Research in Management, 5(2), 18-27. https://hal.archives-ouvertes.fr/hal-02546796

Zeithaml, V. A., Parasuraman, A., \& Malhotra, A. (2000). A conceptual framework for understanding e-service quality: Implications for future research and managerial practice. Massachusetts, US: Marketing Science Institute 